\title{
Low bone turnover in premenopausal women with type 2 diabetes mellitus as an early process of diabetes-associated bone alterations: a cross-sectional study
}

Dyah Purnamasari ${ }^{1 *}$, Melisa D. Puspitasari ${ }^{2}$, Bambang Setiyohadi ${ }^{3}$, Pringgodigdo Nugroho ${ }^{4}$ and Harry Isbagio $^{3}$

\begin{abstract}
Background: Individuals with Diabetes Mellitus (DM) are at increased risk for fracture due to the decrease in bone strength and quality. Serum procollagen type I intact N-terminal (P1NP) and serum C-terminal cross-linking telopeptide of type I collagen (CTX) as markers of bone formation and resorption, respectively, have been reported to be decreased in T2DM. It remains unclear whether diabetes-associated alterations in the bone turnover of T2DM individuals are related to the longer duration of the disease or may occur earlier. Furthermore, previous studies on BTMs in T2DM individuals have mostly been done in postmenopausal women with T2DM, which might have masked the DM-induced alterations of bone turnover with concurrent estrogen deficiency. This study aims to assess the levels of serum P1NP and CTX as markers of bone turnover in premenopausal women with and without T2DM.
\end{abstract}

Methods: This cross-sectional study involves 41 premenopausal women with T2DM, and 40 premenopausal women without DM. Sampling was done consecutively. P1NP and CTX measurement was done using the electrochemiluminescence immunoassay (ECLIA) method. Other data collected include levels of HbA1C, ALT, creatinine, eGFR and lipid profile.

Results: Median (interquartile range) P1NP in T2DM is $29.9 \mathrm{ng} / \mathrm{ml}(24.7-41.8 \mathrm{ng} / \mathrm{ml})$, while in non-DM is $37.3 \mathrm{ng} / \mathrm{ml}$, ( $30.8-47.3 \mathrm{ng} / \mathrm{ml} ; p=0.007)$. Median (interquartile range) CTX in T2DM is $0.161 \mathrm{ng} / \mathrm{ml}(0.106-0.227 \mathrm{ng} / \mathrm{ml})$, while in nonDM is $0.202 \mathrm{ng} / \mathrm{ml}(0.166-0.271 \mathrm{ng} / \mathrm{ml} ; p=0.0035)$. Levels of P1NP and CTX in the T2DM group did not correlate with the duration of disease, age, $\mathrm{BMl}$ or the levels of $\mathrm{HbA1C}$.

Conclusions: Premenopausal women with T2DM indeed have lower bone turnover when compared with non-DM controls. This significantly lower bone turnover process starts relatively early in the premenopausal age, independent of the duration of DM. Gaining understanding of the early pathophysiology of altered bone turnover may be key in developing preventive strategies for diabetoporosis.

Keywords: T2DM, P1NP, CTX, Bone turnover, Premenopause, Diabetoporosis

\footnotetext{
* Correspondence: dyah_p_irawan@yahoo.com

${ }^{1}$ Division of Metabolism and Endocrinology, Department of Internal

Medicine, Faculty of Medicine Universitas Indonesia, Cipto Mangunkusumo

Hospital, J. Salemba 6, Jakarta 10430, Indonesia

Full list of author information is available at the end of the article
} 


\section{Background}

Diabetes mellitus (DM) is a chronic metabolic disorder with an increasing prevalence worldwide. Common late complications of DM are microvascular diseases including nephropathy, retinopathy, neuropathy, and macrovascular disease such as acute coronary syndrome. However, osteoporotic fracture is increasingly recognized as an important complication in both men and women with type $1 \mathrm{DM}$ (T1DM) and type 2 DM (T2DM). Diabetic osteopathy, or may also termed as "diabetoporosis" [1], is diabetesassociated bone alterations that are characterized by a decrease in bone quality, leading to an increased risk of bone fracture in both types of DM [2, 3]. A metaanalysis of 5 studies reported that T1DM is associated with an overall relative risk (RR) of 8,9 (95\% CI 7,1-11,2) for hip fractures when compared with an age-matched nondiabetic population [4]. Similarly, adults with T2DM have a $50 \%-80 \%$ higher risk of hip fractures $[5,6]$ as well as of extremity fractures [5, 7].

While individuals with T1DM showed decreased bone mass density (BMD) [8-13], T2DM is often characterized by increased or unchanged BMD [5, 14-18]. Thus, bone fragility in T2DM depends on microarchitectural changes that is largely determined by increased cortical porosity in T2DM individuals compared to non-diabetic controls rather than the reduction in bone mineral mass [19-22]. The mechanisms of DM-induced bone fragility in T1DM and T2DM are complex and only partially overlap [23]. It was thought that $\beta$-cell failure and low levels of IGF1 disrupt osteoblasts function during growth in T1DM, resulting in low peak bone mass at a young age [24]. In contrast, glucose toxicity, advanced glycation end-products (AGEs), cytokines and adipokines that are affecting osteocyte, bone turnover and collagen affect T2DM individuals at a later age [25].

Data from the study of De Liefde et al. suggested an association between the duration of T2DM and the risk of fractures, as the increased fracture risk found in subjects with DM was restricted to subjects with already established and treated DM only [26]. However, it remains unclear whether changes in bone turnover of T2DM individuals are related to the longer duration of disease or may occur earlier. Data on altered bone metabolism in T2DM have mostly included older, postmenopausal women, that did not make the distinction between T1DM and T2DM or between men and women. Furthermore, estrogen is an important determinant of bone health, which dramatically decreases upon menopause [27]. It is not well-established whether bone fragility in diabetes mirror those found in primary osteoporosis, which occurs frequently in postmenopausal women, but in different proportions, or whether there were particular alterations in the bone of individuals with DM that are not found in primary osteoporosis [1]. Regardless, clinical studies performed on postmenopausal women with T2DM would not be able to exclude the confounding effect of estrogen deficiency on bone metabolism in T2DM. Only one prior study examined BMD and bone turnover markers in both pre- and post-menopausal women with DM. Although showing that post-menopausal women had lower BMD compared with pre-menopausal women, this study found no difference in the levels of bone formation marker in the pre-menopausal women when compared to the reference values, as measured using osteocalcin [28].

Changes in bone turnover can be asessed by measurements of serum levels of C-terminal cross-linking telopeptide of type I collagen (CTX) and procollagen type I intact $\mathrm{N}$-terminal (P1NP), which have been recommended as markers of bone resorption and formation, respectively [29]. The early pathophysiology of altered bone turnover in T2DM remains largely unknown, and informative data may aid in developing preventive strategies for diabetoporosis. To the best of our knowledge, no study has provided data on whether BTM in premenopausal T2DM women is altered. This study aimed to assess whether changes in bone turnover occur early in T2DM by measuring levels of the bone resorption and formation markers, CTX and P1NP, in premenopausal women with T2DM.

\section{Methods}

\section{Study population}

We performed a cross-sectional study enrolling 81 premenopausal women aged $>35$ years: 41 subjects with T2DM and 40 subjects without diabetes to assess the levels of serum P1NP and CTX as markers of bone turnover in premenopausal women. From April to August 2017, we consecutively recruited subjects from the outpatient clinic in several hospitals in Jakarta (Cipto Mangunkusumo Hospital, Persahabatan Hospital, Tugu Koja Hospital and Kemayoran Hospital). All T2DM individuals had been diagnosed according to American Diabetes Association criteria (2016) for at least 5 years. All subjects were malay in race, and had neither hepatic, gastrointestinal, or thyroid diseases nor other secondary causes for low BMD. None of the subjects had been treated with steroid for more than 3 months in the past 3 years, hormone therapy or hormonal contraception, bisphosphonates, antipsychotic drugs, anticonvulsant drugs, hydrochlorothiazides, or thiazolidinediones that might affect bone mass. Subjects with stage 4 and 5 chronic kidney disease and BMI lower than 18.5 were excluded.

\section{Biochemical measurements}

Samples of venous blood were collected in EDTAanticoagulated tubes (BD Vacutainer, Becton Dickinson) in the morning after fasting overnight. Samples were centrifuged immediately after collection at $4000 \mathrm{~g}$ for $8 \mathrm{~min}$. Plasma were aliquoted and stored at $-80{ }^{\circ} \mathrm{C}$ until 
examination. Serum levels of CTX (detection range: 0,010-6 ng/ml) and P1NP (detection range: $5-1200 \mathrm{ng} / \mathrm{ml}$ ) were measured by using automated electrochemiluminescent sandwich antibody assay (ECLIA) on Cobas ${ }^{\circ}$ analyzer (Roche Diagnostics, Manheim, Germany).

\section{Ethical aspects}

The study was approved by the Health Research Ethics Committee of University of Indonesia and Cipto Mangunkusumo Hospital, Jakarta, Indonesia. All participants provided written informed consent to participate.

\section{Statistical analyses}

Data were expressed as median and interquartile range (IQR). Values in groups were compared by T-test or Mann Whitney $U$ test depending on the distribution of the variable of interest. The Pearson (for normally distributed data) or Spearman correlation coefficient (for non-normally distributed data) was used for analyses of correlations. All analyses were performed with Graphpad Prism version 7 (San Diego, CA, USA). $P<0.05$ were considered statistically significant.

\section{Results}

\section{Subject characteristics}

Clinical characteristics for the study groups are shown in Table 1. All subjects included in this study were premenopausal women. T2DM individuals had higher

Table 1 Characteristics of subjects

\begin{tabular}{lll}
\hline & T2DM & Non-DM Controls \\
\hline Number & 41 & 40 \\
Age (years) & $45(41-49)$ & $39(37-45)$ \\
Duration of DM (years) & $9(5-12)$ & NA \\
BMl (kg/m²) & $26(23-31)$ & $25(23-29)$ \\
HbA1C (\%) & $10(7.7-11.6)$ & $5.5(5.2-5.8)$ \\
Creatinine (mg/dl) & $0.6(0.5-0.8)$ & $0.7(0.6-0.7)$ \\
eGFR (mL/min/1,73 m²) & $106(87-115)$ & $110(106-116)$ \\
SGPT (U/l) & $19(11-25)$ & $16(11-21)$ \\
Triglycerides (mg/dl) & $158(96-198)$ & ND \\
LDL (mg/dl) & $141(117-163)$ & ND \\
HDL (mg/dl) & $49(38-54)$ & ND \\
Total cholesterol (mg/dl) & $197(179-230)$ & ND \\
Antidiabetics & & \\
- Metformin (\%) & $7(17)$ & NA \\
- Metformin + Sulfonylurea (\%) & $11(27)$ & NA \\
- Insulin (\%) & $14(34)$ & NA \\
- Combined therapy (\%) & $8(20)$ & NA \\
- No treatment (\%) & $1(2)$ & NA \\
\hline Data depicted are medan with inter & &
\end{tabular}

Data depicted are median with interquartile range (IQR) unless otherwise indicated. Statistical differences are analyzed by using T-test or Mann-Whitney $U$ test. NA, not applicable; ND, not determined median age (interquartile range, IQR; $45,41-49$ years vs. 39 , 37-45 years, $p=0.0004$ ) than non-diabetic controls. Median HbA1c levels of the T2DM group were 10\% (7.7-11.6), and median T2DM duration was 9 years (512 years). Fourteen (34\%) of the T2DM individuals were on insulin treatment, 7 on metformin alone and 11 on a combination of metformin and sulfonylurea while one did not use any treatment. There were 12 T2DM subjects and 7 non-diabetic controls with $\mathrm{BMI}>=30$. None of the subjects consume alcohol or smoke. That CTX is excreted in the urine is an important consideration for studies in T2DM which involves patients with chronic kidney disease, which have been excluded from our study.

\section{Premenopausal women with T2DM had lower bone turnover than non-DM controls}

T2DM individuals demonstrated a significantly lower CTX, a marker of bone resorption, and P1NP, a marker of bone formation. Median values of CTX in the T2DM group were $0.161 \mathrm{ng} / \mathrm{ml}(0.106-0.227 \mathrm{ng} / \mathrm{ml})$, lower when compared to the non-diabetic group $(0.202 \mathrm{ng} / \mathrm{ml}, 0.166-0.271 \mathrm{ng} / \mathrm{ml}$; $p=0.0035$; Fig. 1). Similarly, P1NP levels were also lower in the T2DM subjects $(29.9 \mathrm{ng} / \mathrm{ml}, 24.7-41.8 \mathrm{ng} / \mathrm{ml})$ compared to the non-diabetic $(37.3 \mathrm{ng} / \mathrm{ml}, 30.8-47.3 \mathrm{ng} / \mathrm{ml}$; $p=0.007$ ). Levels of CTX and P1NP correlated positively with one another (Spearman $R=0.586, P<0.0001$ ). CTX is excreted in the urine, and CTX levels in the T2DM subjects negatively correlated with estimated glomerular filtration rate (eGFR; $R=-0.36, p=0.02$ ), whereas this correlation was not observed for P1NP $(R=-0.17, p=0.28)$.

\section{Correlations between bone turnover markers with age and different clinical parameters}

There were no statistically significant correlations between CTX and P1NP levels of T2DM subjects with age $(p=0.38$ and $p=0.66)$, duration of $\mathrm{DM}(p=0.76$ and $p=0.12)$ and levels of $\operatorname{HbA1C}(p=0.26$ and $p=0.27$; Fig. 2$)$. We also did not find correlations between the BTMs and LDL, HDL, total cholesterol, or BMI. Median CTX and P1NP levels were comparable in subjects with or without insulin (CTX: $0.16 \mathrm{ng} / \mathrm{ml}, 0.11-0.21 \mathrm{ng} / \mathrm{ml}$ vs. $0.16 \mathrm{ng} / \mathrm{ml}, 0.10$ $0.24 \mathrm{ng} / \mathrm{ml}, p=0.92$; P1NP: $29 \mathrm{ng} / \mathrm{ml}, 25-43 \mathrm{ng} / \mathrm{ml}$ vs. $30.6 \mathrm{ng} / \mathrm{ml}, 22.8-41.9 \mathrm{ng} / \mathrm{ml}, p=0.65)$, as well as in those with or without metformin (CTX: $0.14 \mathrm{ng} / \mathrm{ml}$, $0.9-0.22 \mathrm{ng} / \mathrm{ml}$ vs. $0.17 \mathrm{ng} / \mathrm{ml}, 0.13-0.24 \mathrm{ng} / \mathrm{ml}, p=$ 0.17; P1NP: $30 \mathrm{ng} / \mathrm{ml}, 23.8-38.2 \mathrm{ng} / \mathrm{ml}$ vs. $35.4 \mathrm{ng} / \mathrm{ml}$, $25.9-51.8 \mathrm{ng} / \mathrm{ml}, p=0.20$ ).

\section{Discussion}

Our study reveals three important findings. First, women with T2DM indeed have lower bone turnover when compared with non-DM controls. Second, this significantly lower bone turnover process in T2DM women starts early in the premenopausal age independent of the duration of 


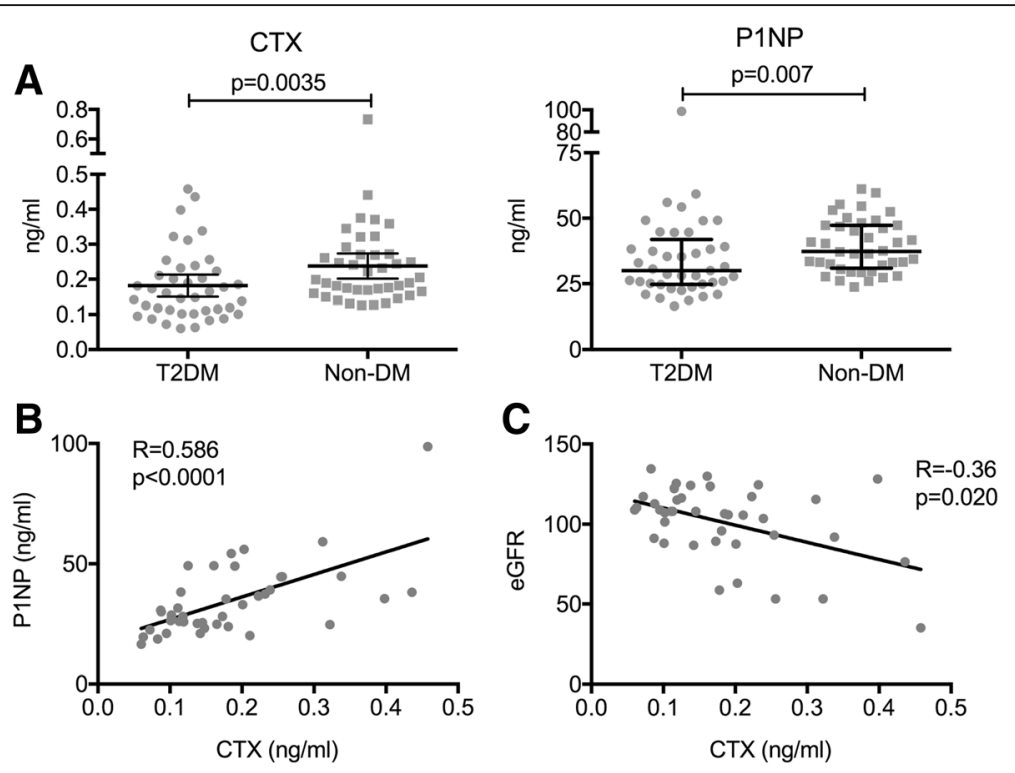

Fig. 1 Lower bone turnover in premenopausal women with T2DM compared to controls. a Individuals with T2DM had lower levels of CTX (left panel) and P1NP (right panel) when compared to non-DM controls. b Positive correlation was found between P1NP and CTX level, c Negative correlation was found between CTX level and eGFR

DM. Third, we did not find any difference in the levels of BTMs between those with or without insulin or metformin use. To the best of our knowledge, this is the first study measuring bone turnover markers in premenopausal women with T2DM. Our findings are in agreement with previous studies which reported lower bone resorption [30-38] and bone formation [35, 39] in T2DM individuals.
T2DM, in contrast with T1DM, is interestingly characterized by increased or unchanged bone mineral density (BMD) [5, 14-18]. It is therefore the severe deficit in bone quality and changes to the bone micro-architecture, as depicted by increased bone cortical porosity T2DM, that underlies fragility fractures in T2DM [19, 30, 40, 41]. Despite their lower bone turnover, T2DM individuals
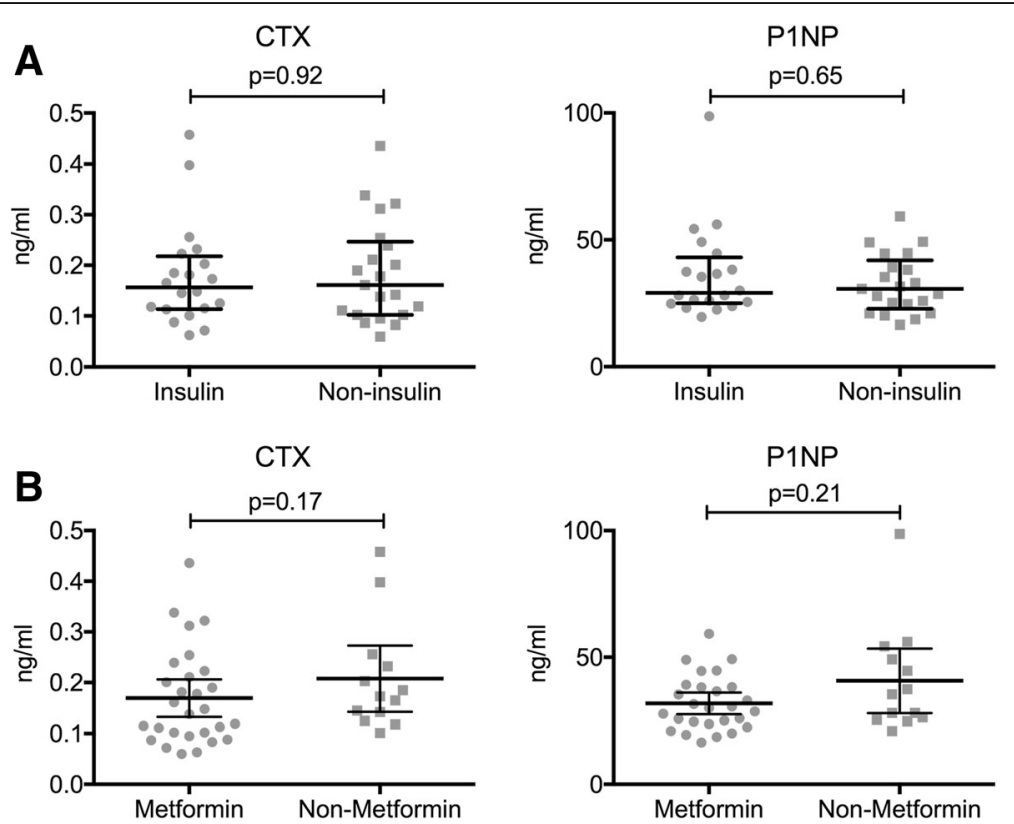

Fig. 2 There was no correlation between insulin or metformin use with bone turnover in T2DM. a Spearman correlation of CTX levels and eGFR in T2DM individuals. b CTX (upper and lower left panels) and P1NP levels (upper and lower right panels) in individuals with and without insulin or metformin use 
have increased bone fragility that cannot be captured by measuring BMD alone [39, 42]. Data showed that the higher BMD in T2DM was not associated with bone geometrical instability or bending strength [43]. However, a study by Burghardt and colleagues used a high-resolution peripheral quantitative computed tomography that enabled assessment of volumetric BMD (vBMD) independently in cortical and trabecular compartments of the bone. T2DM subjects, especially those with previous fracture, showed marked levels of intracortical porosity with an extremely dense trabecular bone in the peripheral region adjacent to the cortex, an assessment that is not captured by conventional measurement of BMD. The authors concluded that this a potential explanation for the inability of BMD measurements to explain increased fracture incidence in patients with T2DM [22]. Another study also reported lower cortical vBMD in T2DM individuals [44]. An alternative explanation for the increased BMD seen in T2DM individuals is the relatively heightened state of bone mineralization as a result of a slowing down in the process of replacing older, more densely mineralized bone with younger, less densely mineralized bone [42].

The duration of T2DM is thought to contribute to the development of bone fragility in T2DM [26]. This notion is supported by studies reporting the association between fracture risk and diabetic microvascular complications such as retinopathy [15], neuropathy [45] and cerebrovascular diseases [46]. It is also thought that long-term DM individuals suffer from more DM-related complications which consequently increase their risk for falling [26]. Furthermore, hyperglycemia which occurs for an extended period of time induces higher levels of AGEs in the bone collagen $[47,48]$, which negatively correlated with the material and biomechanical properties of both the cortical and cancellous bone [49]. AGEs, which are markedly increased in T2DM individuals [50], are diverse compounds generated through the non-enzymatic glycation or glycoxidation of proteins, lipids, and nucleic acids. AGEs interfere with normal osteoblast function, attachment to the collagen matrix, and impair osteoblast development. AGEs may also decrease bone resorption by alteration of the structural integrity of matrix proteins and inhibiting the osteoclastic differentiation. AGEs crosslinking in collagen also leads to more brittle bones that are less able to deform before fracturing [51]. CTX is the degradation product of type I collagen [29] and is used in numerous studies in T2DM as a marker of bone resorption [52]. and there is the possibility that the degraded type I collagen might have already been glycated in diabetic patients. Despite this, to date, there is no method currently available that can differentially measure glycated CTX from unglycated CTX.

That insulin and metformin usage in our study was not associated with levels of BTMs were not surprising.
Although fractures were shown to be increased in T2DM individuals treated with insulin [53], it appeared that the more aggressive glycemic control in elderly individuals with long term disease might increase microvascular complications, such as diabetic retinopathy, and hypoglycemic events and thus the risk for falls and fractures [54]. Metformin, the first line drug for DM, was previously found from most clinical studies to have positive or neutral effect on BMD and fracture risk in large cohorts [55-57].

Whether individuals with T2DM has bone alterations that are specific for T2DM, or whether it is similar to primary osteoporosis but occur in different proportions have not yet been well-established [1]. Interestingly, our data also revealed that changes in the bone turnover of these subjects reveal, at least clinically, a profile that is more similar to those associated with T2DM, with decreased bone resorption, rather than with increasing age or primary osteoporosis, where increased bone resorption is often seen [58]. We did not find any association between levels of CTX and P1NP with the duration of DM or HbA1C levels, as previously reported in other studies $[33,59,60]$. A study by Kanazawa et al. indicated that it was changes in $\mathrm{HbA} 1 \mathrm{C}$ during glycemic control, rather than baseline $\mathrm{HbA1C}$, that was associated with changes in bone formation [61], which might explain our lack of correlation between the BTMs and HbA1C in our study. This study is performed in the Indonesian population with all subjects being of Malay ethnicity. Some studies indicate that there were inherent differences in bone turnover between the different ethnicities [62-67]. However, others suggest that ethnicity per se is not important, and that apparent ethnic differences in rates of bone loss were largely explained by differences in body weight $[29,68,69]$. Studies also reported that levels of P1NP and CTX may be influenced by BMI [70], of which did not differ among groups in our study. Gender differences in BMD, bone structure and the risk of fracture in individuals with diabetes have been acknowledged, with women being particularly at risk for DM-associated bone alterations [71]. It remains largely unclear to what extent hypoglycaemic drugs are gender-specific. Only thiazolidinediones were reported to have negative effects on bone metabolism in women [72-74]. Although our study only involved female subjects, there were none who were on thiazolidinediones.

Better knowledge on how DM and its treatments influence bone tissue may be the basis of effective prevention of fragility fractures in individuals with DM. Currently, recommendations for diabetoporosis management include glycemic control, adequate intake of calcium and vitamin $\mathrm{D}$, screening for low BMD, and prevention and treatment of diabetic complications [75]. Our study emphasizes that changes in bone metabolism occur early and may warrant preventive efforts or pharmacological interventions when 
needed, although this needs well-designed clinical trials of anti-osteoporotic drugs specifically for the diabetic population.

The limitations of our study include the cross-sectional design which measures the investigated parameters in a single time point, and the small sample size of this study. Furthermore, data on BMD from dual energy $x$-ray absorptiometry is not available, limiting our assessment into the relationship between early alterations of the bone turnover markers and bone mineralization. Lastly, data on hormonal status of these subjects were also not available, and would have provided information on the correlation between hormonal status and bone metabolism in the premenopausal women. Despite the above limitations, this study remains as the only study to date revealing a decrease in bone turnover markers in premenopausal women with T2DM.

\section{Conclusion}

Premenopausal women with T2DM had lower levels of CTX and P1NP, which reflects lower bone turnover, compared to non-DM controls, independent of age and duration of disease. Our results indicate that alterations in bone turnover occur relatively early in the course of the disease, and prior to the occurrence of menopause. As T2DM individuals are at increased risk of fracture, understanding the early pathophysiology of altered bone turnover may be key in developing preventive strategies for diabetoporosis.

\begin{abstract}
Abbreviations
AGE: advanced glycation endproducts; BMD: bone mineral density; BMl: body mass index; BTM: bone turnover marker; CTX: C-terminal cross-linking telopeptide of type I collagen; DM: diabetes mellitus; eGFR: estimated glomerular filtration rate; HDL: high density lipoprotein; LDL: low density lipoprotein; P1NP: procollagen type I intact N-terminal (P1NP) and serum; T1DM: type 1 diabetes mellitus; T2DM: type 2 diabetes mellitus
\end{abstract}

\section{Acknowledgements}

Not applicable

\section{Funding}

The authors receive research grant from Hibah Penelitian Unggulan Perguruan Tinggi (PUPT) from the Directorate of Research and Public Services of the Indonesiaan Ministry of Research, Technology and Higher Education.

\section{Availability of data and materials}

The datasets used and/or analysed during the current study are available from the corresponding author on reasonable request.

\section{Authors' contributions}

DP and BS initiated and designed the study. MD collected, performed statistical analyses and interpreted the data, and was responsible for project administration and management of resources. DP validated the data. DP, BS, $\mathrm{PN}, \mathrm{HI}$ supervised the study and interpreted the data. $\mathrm{HI}$ acquired the funding for financing this study. MD wrote the original draft of the manuscript. All authors reviewed and approved the final manuscript.

\section{Ethics approval and consent to participate}

The study was approved by the Health Research Ethics Committee of Universitas Indonesia and Cipto Mangunkusumo Hospital, Jakarta, Indonesia. All participants provided written informed consent to participate.
Consent for publication

Not applicable

\section{Competing interests}

The authors declare that they have no competing interests.

\section{Publisher's Note}

Springer Nature remains neutral with regard to jurisdictional claims in published maps and institutional affiliations.

\section{Author details}

'Division of Metabolism and Endocrinology, Department of Internal Medicine, Faculty of Medicine Universitas Indonesia, Cipto Mangunkusumo Hospital, Jl. Salemba 6, Jakarta 10430, Indonesia. ${ }^{2}$ Department of Internal Medicine, Faculty of Medicine Universitas Indonesia, Cipto Mangunkusumo Hospital, Jakarta, Indonesia. ${ }^{3}$ Division of Rheumatology, Department of Internal Medicine, Faculty of Medicine Universitas Indonesia, Cipto Mangunkusumo Hospital, Jakarta, Indonesia. ${ }^{4}$ Division of Nephrology and Hypertension, Department of Internal Medicine, Faculty of Medicine Universitas Indonesia, Cipto Mangunkusumo Hospital, Jakarta, Indonesia.

Received: 6 October 2017 Accepted: 21 November 2017

Published online: 29 November 2017

\section{References}

1. Ferrari S. Diabetes and bone. Calcif Tissue Int. 2017:100(2):107-8.

2. Nyman JS, Even JL, Jo C-H, Herbert EG, Murry MR, Cockrell GE, Wahl EC, Bunn RC, Lumpkin CK, Fowlkes JL. Increasing duration of type 1 diabetes perturbs the strength-structure relationship and increases brittleness of bone. Bone. 2011;48(4):733-40.

3. Thrailkill KM, Lumpkin CK, Bunn RC, Kemp SF, Fowlkes JL. Is insulin an anabolic agent in bone? Dissecting the diabetic bone for clues. Am J Physiol Endocrinol Metab. 2005;289(5):E735-45.

4. Janghorbani M, Van Dam RM, Willett WC, FB H. Systematic review of type 1 and type 2 diabetes mellitus and risk of fracture. Am J Epidemiol. 2007;166(5):495-505.

5. Schwartz AV, Sellmeyer DE, Ensrud KE, Cauley JA, Tabor HK, Schreiner PJ, Jamal SA, Black DM, Cummings SR. Older women with diabetes have an increased risk of fracture: a prospective study. J Clin Endocrinol Metab. 2001;86(1):32-8

6. Janghorbani M, Feskanich D, Willett WC, Hu F. Prospective study of diabetes and risk of hip fracture the nurses' health study. Diabetes Care. 2006;29(7): 1573-8.

7. Bonds DE, Larson JC, Schwartz AV, Strotmeyer ES, Robbins J, Rodriguez BL, Johnson KC, Margolis KL. Risk of fracture in women with type 2 diabetes: the Women's health initiative observational study. J Clin Endocrinol Metab. 2006;91(9):3404-10.

8. Munoz-Torres M, Jodar E, Escobar-Jimenez F, Lopez-Ibarra P, Luna J. Bone mineral density measured by dual $\mathrm{X}$-ray absorptiometry in Spanish patients with insulin-dependent diabetes mellitus. Calcif Tissue Int. 1996;58(5):316-9.

9. Miazgowski T, Czekalski S. A 2-year follow-up study on bone mineral density and markers of bone turnover in patients with long-standing insulindependent diabetes mellitus. Osteoporos Int. 1998;8(5):399-403.

10. Jehle $P$, Jehle D, Mohan S, Bohm B. Serum levels of insulin-like growth factor system components and relationship to bone metabolism in type 1 and type 2 diabetes mellitus patients. J Endocrinol. 1998;159(2):297-306.

11. Tuominen JT, Impivaara O, Puukka P, Rönnemaa T. Bone mineral density in patients with type 1 and type 2 diabetes. Diabetes Care. 1999;22(7):1196-200.

12. Gallacher S, Fenner J, Fisher B, Quin J, Fraser W, Logue F, Cowan R, Boyle I, MacCuish A. An evaluation of bone density and turnover in premenopausal women with type 1 diabetes mellitus. Diabet Med. 1993;10(2):129-33.

13. Weber G, Beccaria L, De'Angelis M, Mora S, Galli L, Cazzuffi M, Turba F, Frisone $F$, Guarneri M, Chiumello G. Bone mass in young patients with type I diabetes. Bone Miner. 1990;8(1):23-30.

14. Cummings SR, Nevitt MC, Browner WS, Stone K, Fox KM, Ensrud KE, Cauley J, Black D, Vogt TM. Risk factors for hip fracture in white women. N Engl J Med. 1995;332(12):767-74.

15. Ivers RQ, Cumming RG, Mitchell P, Peduto AJ. Diabetes and risk of fracture: the Blue Mountains eye study. Diabetes Care. 2001;24(7):1198-203.

16. Nicodemus KK, Folsom AR. Type 1 and type 2 diabetes and incident hip fractures in postmenopausal women. Diabetes Care. 2001;24(7):1192-7. 
17. Wakasugi M, Wakao R, Tawata M, Gan N, Koizumi K, Onaya T. Bone mineral density measured by dual energy X-ray absorptiometry in patients with non-insulin-dependent diabetes mellitus. Bone. 1993;14(1):29-33.

18. van Daele PL, Stolk RP, Burger H, Algra D, Grobbee DE, Hofman A Birkenhager JC, Pols HA. Bone density in non-insulin-dependent diabetes mellitus: the Rotterdam study. Ann Intern Med. 1995;122(6):409-14.

19. Pritchard JM, Giangregorio LM, Atkinson SA, Beattie KA, Inglis D, loannidis $G$, Gerstein H, Punthakee Z, Adachi JD, Papaioannou A. Changes in trabecular bone microarchitecture in postmenopausal women with and without type 2 diabetes: a two year longitudinal study. BMC Musculoskelet Disord. 2013;14(1):114.

20. Pritchard JM, Giangregorio LM, Atkinson SA, Beattie KA, Inglis D, loannidis G, Punthakee Z, Adachi J, Papaioannou A. Association of larger holes in the trabecular bone at the distal radius in postmenopausal women with type 2 diabetes mellitus compared to controls. Arthritis Care Res (Hoboken). 2012;64(1):83-91.

21. Yu E, Putman MS, Derrico N, Abrishamanian-Garcia G, Finkelstein JS, Bouxsein ML. Defects in cortical microarchitecture among African-American women with type 2 diabetes. Osteoporos Int. 2015;26(2):673-9.

22. Burghardt AJ, Issever AS, Schwartz AV, Davis KA, Masharani U, Majumdar S, Link TM. High-resolution peripheral quantitative computed tomographic imaging of cortical and trabecular bone microarchitecture in patients with type 2 diabetes mellitus. J Clin Endocrinol Metab. 2010;95(11):5045-55.

23. Napoli N, Chandran M, Pierroz DD, Abrahamsen B, Schwartz AV, Ferrari SL. Mechanisms of diabetes mellitus-induced bone fragility. Nat Rev Endocrinol. 2017;13(4):208-19.

24. Hough F, Pierroz D, Cooper C, Ferrari SL. MECHANISMS IN ENDOCRINOLOGY: Mechanisms and evaluation of bone fragility in type 1 diabetes mellitus. Eur J Endocrinol. 2016;174(4):R127-38.

25. Napoli N, Strollo R, Paladini A, Briganti SI, Pozzilli P, Epstein S. The alliance of mesenchymal stem cells, bone, and diabetes. Int J Endocrinol. 2014;

26. De Liefde I, Van der Klift M, De Laet C, Van Daele P, Hofman A, Pols H. Bone mineral density and fracture risk in type-2 diabetes mellitus: the Rotterdam study. Osteoporos Int. 2005;16(12):1713-20.

27. Weitzmann MN, Pacifici R. Estrogen deficiency and bone loss: an inflammatory tale. J Clin Invest. 2006;116(5):1186.

28. Christensen J, Svendsen O. Bone mineral in pre-and postmenopausal women with insulin-dependent and non-insulin-dependent diabetes mellitus. Osteoporos Int. 1999;10(4):307-11.

29. Vasikaran S, Eastell R, Bruyère O, Foldes A, Garnero P, Griesmacher A, McClung $\mathrm{M}$, Morris $\mathrm{H}$, Silverman S, Trenti T. Markers of bone turnover for the prediction of fracture risk and monitoring of osteoporosis treatment: a need for international reference standards. Osteoporos Int. 2011;22(2):391-420.

30. Farr JN, Drake MT, Amin S, Melton L, McCready LK, Khosla S. Vivo assessment of bone quality in postmenopausal women with type 2 diabetes. J Bone Miner Res. 2014;29(4):787-95.

31. Jiajue $R$, Jiang $Y$, Wang $O$, Li M, Xing X, Cui L, Yin J, Xu L, Xia W. Suppressed bone turnover was associated with increased osteoporotic fracture risks in non-obese postmenopausal Chinese women with type 2 diabetes mellitus. Osteoporos Int. 2014;25(8):1999-2005.

32. Akin O, Göl K, Aktürk M, Erkaya S. Evaluation of bone turnover in postmenopausal patients with type 2 diabetes mellitus using biochemical markers and bone mineral density measurements. Gynecol Endocrinol. 2003;17(1):19-29.

33. Reyes-Garcia R, Rozas-Moreno P, Lopez-Gallardo G, Garcia-Martin A, Varsavsky M, Aviles-Perez MD, Munoz-Torres M. Serum levels of bone resorption markers are decreased in patients with type 2 diabetes. Acta Diabetol. 2013;50(1):47-52.

34. Yamamoto $M$, Yamaguchi T, Nawata K, Yamauchi M, Sugimoto T. Decreased PTH levels accompanied by low bone formation are associated with vertebral fractures in postmenopausal women with type 2 diabetes. J Clin Endocrinol Metab. 2012;97(4):1277-84

35. Manavalan J, Cremers S, Dempster D, Zhou H, Dworakowski E, Kode A Kousteni S, Rubin M. Circulating osteogenic precursor cells in type 2 diabetes mellitus. J Clin Endocrinol Metab. 2012;97(9):3240-50.

36. Bhattoa HP, Onyeka U, Kalina E, Balogh A, Paragh G, Antal-Szalmas P, Kaplar M. Bone metabolism and the 10-year probability of hip fracture and a major osteoporotic fracture using the country-specific FRAX algorithm in men over 50 years of age with type 2 diabetes mellitus: a case-control study. Clin Rheumatol. 2013;32(8):1161.

37. Gerdhem P, Isaksson A, Åkesson K, Obrant KJ. Increased bone density and decreased bone turnover, but no evident alteration of fracture susceptibility in elderly women with diabetes mellitus. Osteoporos Int. 2005;16(12): 1506-12.

38. Maghbooli Z, Emamgholipour S, Hossein-Nezhad A, Shirzad M, Firuzjaee SG. Suitable bone markers assessing bone status in patients with both coronary artery disease and diabetes. J Diabetes Metab Disord. 2016;15(1):35.

39. Chen $\mathrm{H}$, Li X, Yue R, Ren X, Zhang X, Ni A. The effects of diabetes mellitus and diabetic nephropathy on bone and mineral metabolism in T2DM patients. Diabetes Res Clin Pract. 2013;100(2):272-6.

40. Patsch JM, Burghardt AJ, Yap SP, Baum T, Schwartz AV, Joseph GB, Link TM. Increased cortical porosity in type 2 diabetic postmenopausal women with fragility fractures. J Bone Miner Res. 2013;28(2):313-24.

41. Shanbhogue W, Hansen S, Frost M, Jørgensen NR, Hermann AP, Henriksen JE, Brixen K. Compromised cortical bone compartment in type 2 diabetes mellitus patients with microvascular disease. Eur J Endocrinol. 2016;174(2): $115-24$.

42. Seeman E. Reduced bone formation and increased bone resorption: rational targets for the treatment of osteoporosis. Osteoporos Int. 2003;14(3):2-8.

43. Oei L, Zillikens MC, Dehghan A, Buitendijk GH, Castaño-Betancourt MC, Estrada K, Stolk L, Oei EH, van Meurs JB, Janssen JA. High bone mineral density and fracture risk in type 2 diabetes as skeletal complications of inadequate glucose control the Rotterdam study. Diabetes Care. 2013;36(6):1619-28.

44. Samelson EJ, Demissie S, Cupples LA, Zhang X, Xu H, Liu CT, Boyd SK, McLean RR, Broe KE, Kiel DP. Diabetes and deficits in cortical bone density, microarchitecture, and bone size: Framingham HR-pQCT study. J Bone Miner Res. 2017;

45. Miao J, Brismar K, Nyrén O, Ugarph-Morawski A, Ye W. Elevated hip fracture risk in type 1 diabetic patients. Diabetes Care. 2005;28(12):2850-5.

46. Strotmeyer ES, Cauley JA, Schwartz AV, Nevitt MC, Resnick HE, Bauer DC, Tylavsky FA, de Rekeneire N, Harris TB, Newman AB. Nontraumatic fracture risk with diabetes mellitus and impaired fasting glucose in older white and black adults: the health, aging, and body composition study. Arch Intern Med. 2005;165(14):1612-7.

47. Bucala R, Vlassara $H$. Advanced glycosylation end products in diabetic renal and vascular disease. Am J Kidney Dis. 1995;26(6):875-88.

48. Goldin A, Beckman JA, Schmidt AM, Creager MA. Advanced glycation end products. Circulation. 2006;114(6):597-605.

49. Leslie WD, Rubin MR, Schwartz AV, Kanis JA. Type 2 diabetes and bone. J Bone Miner Res. 2012;27(11):2231-7.

50. Makita Z, Radoff S, Rayfield EJ, Yang Z, Skolnik E, Delaney V, Friedman EA, Cerami A, Vlassara H. Advanced glycosylation end products in patients with diabetic nephropathy. N Engl J Med. 1991;325(12):836-42.

51. Vashishth D, Gibson G, Khoury J, Schaffler M, Kimura J, Fyhrie D. Influence of nonenzymatic glycation on biomechanical properties of cortical bone. Bone. 2001;28(2):195-201.

52. Puspitasari MD, Purnamasari $D$, Setyohadi $B$, Isbagio $H$. Bone metabolism and fracture risk in diabetes mellitus. J ASEAN Federation of Endocrine For Soc. 2017:32(2):90

53. Monami M, Cresci B, Colombini A, Pala L, Balzi D, Gori F, Chiasserini V, Marchionni N, Rotella CM, Mannucci E. Bone fractures and hypoglycemic treatment in type 2 diabetic patients. Diabetes Care. 2008;31(2):199-203.

54. Schwartz AV, Vittinghoff E, Sellmeyer DE, Feingold KR, De Rekeneire N, Strotmeyer ES, Shorr RI, Vinik Al, Odden MC, Park SW. Diabetes-related complications, glycemic control, and falls in older adults. Diabetes Care. 2008;31(3):391-6.

55. Vestergaard P, Rejnmark L, Mosekilde L. Relative fracture risk in patients with diabetes mellitus, and the impact of insulin and oral antidiabetic medication on relative fracture risk. Diabetologia. 2005;48(7):1292-9.

56. Napoli N, Strotmeyer ES, Ensrud KE, Sellmeyer DE, Bauer DC, Hoffman AR, TTL D, Barrett-Connor E, Palermo L, Orwoll ES. Fracture risk in diabetic elderly men: the MrOS study. Diabetologia. 2014;57(10):2057-65.

57. Solomon DH, Cadarette SM, Choudhry NK, Canning C, Levin R, Sturmer T. A cohort study of thiazolidinediones and fractures in older adults with diabetes. J Clin Endocrinol Metab. 2009;94(8):2792-8.

58. Demontiero O, Vidal C, Duque G. Aging and bone loss: new insights for the clinician. Ther Adv Musculoskelet Dis. 2012;4(2):61-76.

59. Achemlal L, Tellal S, Rkiouak F, Nouijai A, Bezza A, Derouiche EM, Ghafir D, E Maghraoui A. Bone metabolism in male patients with type 2 diabetes. Clin Rheumatol. 2005;24(5):493-6.

60. Shu A, Yin M, Stein E, Cremers S, Dworakowski E, Ives R, Rubin M. Bone structure and turnover in type 2 diabetes mellitus. Osteoporos Int. 2012;23(2):635-41. 
61. Kanazawa I, Yamaguchi T, Yamauchi M, Yamamoto M, Kurioka S, Yano S, Sugimoto T. Adiponectin is associated with changes in bone markers during glycemic control in type 2 diabetes mellitus. J Clin Endocrinol Metab. 2009:94(8):3031-7.

62. Leder BZ, Araujo AB, Travison TG, McKinlay JB. Racial and ethnic differences in bone turnover markers in men. J Clin Endocrinol Metab. 2007:92(9):3453-7.

63. de Papp AE, Bone HG, Caulfield MP, Kagan R, Buinewicz A, Chen E, Rosenberg E, Reitz RE. A cross-sectional study of bone turnover markers in healthy premenopausal women. Bone. 2007;40(5):1222-30.

64. Henry Y, Eastell R. Ethnic and gender differences in bone mineral density and bone turnover in young adults: effect of bone size. Osteoporos Int. 2000;11(6):512-7.

65. Holvik K, Meyer HE, Søgaard AJ, Selmer R, Haug E, Falch JA. Biochemical markers of bone turnover and their relation to forearm bone mineral density in persons of Pakistani and Norwegian background living in Oslo, Norway: the Oslo health study. Eur J Endocrinol. 2006;155(5):693-9.

66. Ardawi M-SM, Maimani AA, Bahksh TA, Rouzi AA, Qari MH, Raddadi RM. Reference intervals of biochemical bone turnover markers for Saudi Arabian women: a cross-sectional study. Bone. 2010;47(4):804-14.

67. Finkelstein JS, Sowers M, Greendale GA, Lee M-LT, Neer RM, Cauley JA, Ettinger B. Ethnic variation in bone turnover in pre-and early perimenopausal women: effects of anthropometric and lifestyle factors. J Clin Endocrinol Metab. 2002;87(7):3051-6

68. Finkelstein JS, Brockwell SE, Mehta V, Greendale GA, Sowers MR, Ettinger B, Lo JC, Johnston JM, Cauley JA, Danielson ME. Bone mineral density changes during the menopause transition in a multiethnic cohort of women. J Clin Endocrinol Metab. 2008;93(3):861-8.

69. Cifuentes M, Johnson M, Lewis R, Heymsfield S, Chowdhury H, Modlesky C, Shapses $\mathrm{S}$. Bone turnover and body weight relationships differ in normalweight compared with heavier postmenopausal women. Osteoporos Int. 2003:14(2):116-22

70. Weinbrenner T, Zittermann A, Gouni-Berthold I, Stehle P, Berthold H. Body mass index and disease duration are predictors of disturbed bone turnover in anorexia nervosa. A case-control study. Eur J Clin Nutr. 2003;57(10):1262-7.

71. Russo GT, Giandalia A, Romeo EL, Nunziata M, Muscianisi M, Ruffo MC Catalano A, Cucinotta D. Fracture risk in type 2 diabetes: current perspectives and gender differences. Int J Endocrinol. 2016:2016:1615735.

72. Glintborg D, Andersen M, Hagen C, Heickendorff L, Hermann AP. Association of pioglitazone treatment with decreased bone mineral density in obese premenopausal patients with polycystic ovary syndrome: a randomized, placebo-controlled trial. J Clin Endocrinol Metab. 2008;93(5):1696-701.

73. Berberoglu Z, Gursoy A, Bayraktar N, Yazici AC, Bascil Tutuncu N, Guvener Demirag N. Rosiglitazone decreases serum bone-specific alkaline phosphatase activity in postmenopausal diabetic women. J Clin Endocrinol Metab. 2007;92(9):3523-30

74. Grey A, Bolland M, Gamble G, Wattie D, Horne A, Davidson J, Reid IR. The peroxisome proliferator-activated receptor- $\gamma$ agonist rosiglitazone decreases bone formation and bone mineral density in healthy postmenopausal women: a randomized, controlled trial. J Clin Endocrinol Metab. 2007;92(4): 1305-10.

75. Montagnani A, Gonnelli S, Alessandri M, Nuti R. Osteoporosis and risk of fracture in patients with diabetes: an update. Aging Clin Exp Res. 2011;23(2):84-90.

\section{Submit your next manuscript to BioMed Central and we will help you at every step:}

- We accept pre-submission inquiries

- Our selector tool helps you to find the most relevant journal

- We provide round the clock customer support

- Convenient online submission

- Thorough peer review

- Inclusion in PubMed and all major indexing services

- Maximum visibility for your research

Submit your manuscript at www.biomedcentral.com/submit

) Biomed Central 